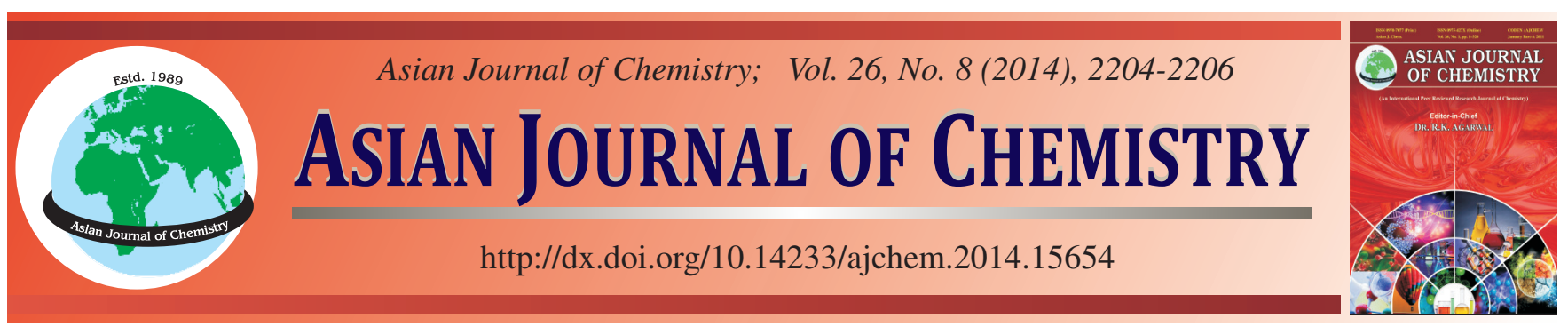

\title{
Chemical Profiles of Essential Oils of Bauhinia Species from South India
}

\author{
Vipinlal Vasudevan ${ }^{1}$, Joseph Mathew, ${ }^{1, *}$ and Sabulal Baby ${ }^{2}$
}

\begin{abstract}
${ }^{1}$ Department of Chemistry, Mar Ivanios College, Thiruvananthapuram-695 015, India
${ }^{2}$ Phytochemistry and Phytopharmacology Division, Jawaharlal Nehru Tropical Botanic Garden and Research Institute, Pacha-Palode, Thiruvananthapuram-695 562, India
\end{abstract}

*Corresponding author: E-mail: jmathewdr@gmail.com

Received: 18 April 2013;

Accepted: 27 August 2013;

Published online: 15 April 2014;

AJC-14992

Essential oils from fresh leaves of Bauhinia tomentosa, B. scandens, B. purpurea and B. malabarica from south India were isolated by hydrodistillation and characterized by GC-MS. Phytol was the major constituent in B. purpurea $(90.38 \%)$, B. scandens $(88.32 \%)$ and $B$. malabarica $(62.17 \%)$. Phytone was the major constituent in $B$. tomentosa $(32.84 \%)$, followed by $\beta$-cubebene $(21.84 \%)$ and $\beta$-caryophyllene $(14.24 \%)$. Monoterpenioids were absent in Bauhinia leaf oils.

Keywords: Bauhinia, Essential oils, GC-MS, Phytol, Phytone, $\beta$-Cubebene, $\beta$-Caryophyllene.

\section{INTRODUCTION}

Genus Bauhinia (Fabaceae) has over 250 species of trees and shrubs mostly distributed in the tropical areas. Bauhinia bark and leaves are used in traditional medicines. B. racemosa is used in treatment of inflammation, headache, fever, tumors, skin infection, dysentery and diarrhea ${ }^{1,2} . B$. microstachya is used for diabetics in herbal medicine ${ }^{3} B$. reticulata and $B$. refescens are used for the treatment of round worm, conjunctivitis, anthrax, dysentery, blood poisoning, leprosy and lung diseases ${ }^{4,5} . B$. purpurea is used as a laxative and carminative drug $^{6}$. B. purpurea is also used for the treatment of diarrhea in sub Himalayan areas ${ }^{7}$. In this study, we report the chemical profiles of leaf volatile oils of four Bauhinia species, viz., $B$. tomentosa, B. scandens, B. purpurea and B. malabarica from south India. Chemical profiles of these four Bauhinia leaf oils are also compared with B. acuminata $^{8}$.

\section{EXPERIMENTAL}

Fresh leaves of B. scandens, B. purpurea and B. malabarica were collected in May 2012 from the campus of Jawaharlal Nehru Tropical Botanic Garden and Research Institute, PachaPalode and B. tomentosa was collected in June 2012 from Peroorkada, Thiruvananthapuram. Bauhinia specimens were identified by Dr. Mathew Dan, Jawaharlal Nehru Tropical Botanic Garden and Research Institute, Palode.

Extraction of essential oils: Fresh leaves of $B$. tomentosa (650 g), B. purpurea (650 g), B. malabarica (650 g) and $B$. scandens $(150 \mathrm{~g})$ were separately hydrodistilled for $6 \mathrm{~h}$ using Clevenger-type apparatus. Pungent smelling, light greenish yellow coloured essential oils were obtained from leaves of $B$. tomentosa $(0.10 \mathrm{~mL}, 0.008 \%, \mathrm{v} / \mathrm{w})$, B. purpurea $(0.10 \mathrm{~mL}$, $0.008 \%$, v/w) and B. malabarica $(0.15 \mathrm{~mL}, 0.009 \%$, v/w). $B$. scandens yielded pungent smelling, white turbid leaf oil $(0.05$ $\mathrm{mL}, 0.006 \%$, v/w). B. scandens and B. purpurea leaves showed a white deposit along with their leaf oils on cooling of the Clevenger apparatus. Leaf oils along with the solidified portions were washed of the distillation apparatus with acetone and kept at $4{ }^{\circ} \mathrm{C}$ until analyzed.

GC-MS analyses: Bauhinia leaf oils were subjected to GC-MS analysis by splitless injection of $1 \mu \mathrm{L}$ of each oil on a Hewlett Packard 6890 gas chromatograph fitted with a crosslinked $5 \%$ PH ME siloxane HP-5 MS capillary column (30 m $\times 0.32 \mathrm{~mm}, 0.25 \mu \mathrm{m}$ coating thickness) coupled with a model 5973 mass detector. GC-MS operation conditions: injector temperature $220{ }^{\circ} \mathrm{C}$; transfer line $240{ }^{\circ} \mathrm{C}$; oven temperature programme $60-246^{\circ} \mathrm{C}\left(3{ }^{\circ} \mathrm{C} / \mathrm{min}\right)$; carrier gas helium, $1.4 \mathrm{~mL} /$ min; detector temperature $250 \mathrm{C}$. Mass spectra: electron impact $\left(\mathrm{EI}^{+}\right)$mode $70 \mathrm{eV}$ with a mass range of $40-450 \mathrm{~m} / \mathrm{z}$ and ion source temperature $250{ }^{\circ} \mathrm{C}$.

Identification of oil constituents: Individual components of Bauhinia leaf oils were identified by Wiley 275 L database matching, comparison of retention times and comparison of mass spectra with published data ${ }^{9}$ (Table-1).

\section{RESULTS AND DISCUSSION}

Phytol, a diterpene alcohol, was detected as the major constituent in Bauhinia purpurea (90.38\%), B. scandens $(88.32 \%)$ and B. malabarica $(62.17 \%)$ leaf oils (Table-1). 


\begin{tabular}{|c|c|c|c|c|c|c|}
\hline \multicolumn{7}{|c|}{$\begin{array}{c}\text { TABLE-1 } \\
\text { CHEMICAL PROFILES OF Bauhinia LEAF OILS FROM SOUTH INDIA }\end{array}$} \\
\hline \multirow{2}{*}{ Constituent } & \multirow{2}{*}{$\begin{array}{l}\text { Retention time, } \\
\text { HP-5 (min.) }\end{array}$} & \multicolumn{5}{|c|}{$\begin{array}{cc} & \text { Percentage } \\
\end{array}$} \\
\hline & & Bauhinia tomentosa & B. scandens & B. purpurea & B. malabarica & B. acuminata* \\
\hline$\alpha$-Copaene & 18.54 & - & - & - & 4.73 & - \\
\hline$\beta$-Elemene & 19.23 & 6.91 & - & - & - & - \\
\hline$\beta$-Caryophyllene & 20.19 & 14.24 & - & - & - & 13.87 \\
\hline$\beta$-Cubebene & 22.63 & 21.84 & - & - & - & - \\
\hline$\alpha$-Humulene & 22.64 & - & - & - & - & 1.76 \\
\hline Isomethyl- $\alpha$-ionone & 22.89 & - & - & - & - & 0.17 \\
\hline$\alpha$-Elemene & 23.23 & - & - & - & 2.84 & - \\
\hline$\beta$-Ionone & 23.94 & - & - & - & - & 0.10 \\
\hline$\beta$-Cadinene & 24.33 & 6.11 & - & - & - & - \\
\hline$\delta$-Cadinene & 24.37 & - & - & - & 12.47 & - \\
\hline$\alpha$-Farnesene & 24.87 & - & - & - & - & 0.10 \\
\hline Cadala-1(10),3,8-triene & 25.04 & - & - & - & 3.26 & - \\
\hline$\alpha$-Elemol & 25.36 & - & - & 1.86 & - & - \\
\hline 1,6,10-Dodecatrien-3-ol & 27.13 & - & - & - & - & 0.26 \\
\hline 3-Hexen-1-ol & 27.32 & - & - & - & - & 0.24 \\
\hline Caryophyllene oxide & 27.68 & - & - & - & - & 3.15 \\
\hline$\beta$-Guaiene & 28.24 & - & - & - & 6.53 & - \\
\hline Humulene epoxide (II) & 28.53 & - & - & - & - & 0.35 \\
\hline$\delta$-Cadinol & 28.74 & - & - & - & 2.66 & - \\
\hline Caryophylla-4(12),8(13)-dien-5 $\alpha$-ol & 29.40 & - & - & - & - & 0.22 \\
\hline Caryophylla-4(12),8(13)-dien-5 $\beta$-ol & 29.61 & - & - & - & - & 1.00 \\
\hline$\alpha$-Muurolol & 29.77 & - & - & - & - & 0.32 \\
\hline Cadalene & 29.90 & - & - & - & 1.53 & - \\
\hline$\alpha$-Cadinol & 30.25 & - & - & - & - & 0.40 \\
\hline Isoaromadendrene epoxide & 30.35 & - & - & - & - & 0.11 \\
\hline Farnesol & 32.80 & - & - & - & - & 0.24 \\
\hline 1-Octadecene & 35.24 & - & - & - & - & 0.26 \\
\hline Phytone & 36.06 & 32.84 & 2.54 & 1.92 & - & - \\
\hline Nonadecane & 37.82 & - & - & 2.82 & - & - \\
\hline Phytol & 44.44 & 10.12 & 88.32 & 90.38 & 62.17 & 65.90 \\
\hline Sclareolide & 46.93 & - & - & - & - & 0.24 \\
\hline Octacosane & 55.91 & - & - & - & - & 0.21 \\
\hline Total & 92.06 & 90.86 & 96.98 & 96.19 & 88.90 & - \\
\hline
\end{tabular}

The turbid leaf oil of $B$. scandens showed only two constituents, phytol $(88.32 \%)$ and phytone $(2.54 \%)$. Phytone (32.84\%), $\beta$-cubebene (21.84\%), $\beta$-caryophyllene (14.24\%) and phytol $(10.12 \%)$ were the major constituents in $B$. tomentosa leaf oil (Table-1). We recently reported $65.90 \%$ phytol in B. acuminata leaf oil, with $\beta$-caryophyllene (13.87 $\%)$ as its second major constituent ${ }^{8}$. Phytol is used in cosmetics, fine fragrances, shampoos, toilet soaps and in non-cosmetic products such as household cleaners and detergents ${ }^{10}$. Phytol is also used as a precursor for the manufacture of vitamins $\mathrm{E}$ and $\mathrm{K} 1^{11,12}$. It is commonly found in its esterified form in green vegetables as the side chain of chlorophyll molecule. Phytanic acid is an acid derivative of phytol and humans obtain it through the consumption of dietary sources. Free phytol, when administered orally, is readily absorbed and converted to phytanic acid in rats and humans ${ }^{13}$. Sumac flea beetle Blepharida rhois was reported to use phytol synthesized by its host plant as a deterrent against predation ${ }^{14}$. Phytone is used as a fragrance agent $^{15,16}$.

Sesquiterpenes and their oxygenated derivatives constituted the second major groups of compounds in Bauhinia leaf oils (Table-1). $\beta$-Caryophyllene is a natural bicyclic sesqui- terpene with a rare cyclobutene ring. It is naturally found as a mixture with $\alpha$-caryophyllene ( $\alpha$-humulene) and isocaryophyllene. It usually finds applications in spice blends, citrus flavors, soaps, detergents, creams and lotions and also in a variety of food products and beverages ${ }^{17,18}$. $\beta$-Caryophyllene is also known for its antiinflammatory and local anesthetic activities ${ }^{19,20}$. Previous studies identified $\beta$-elemene $56.9 \%$, lepidozenol $22.3 \%$, $\beta$-bourbonene $12.4 \%$ (B. aculeata); spathulenol $15.9 \%, \gamma$-elemene $11.8 \%$ (B. brevipes); $\alpha$-copaene $28.8 \%, \beta$-caryophyllene $18.5 \%$, bicyclogermacrene $14.0 \%$, $\alpha$-humulene $11.8 \%$ (B. foficata); spathulenol $27.0 \%, \beta$-caryophyllene $17.4 \%$, bicyclogermacrene $12.3 \%$, isospathulenol $10.8 \%$ (B. longifolia); $\beta$-caryophyllene $46.6 \%, \alpha$-elemene $22.6 \%$, spathulenol $14.1 \%$ (B. rufa) and germacrene D $24.7 \%$, $\alpha$-elemene $18.7 \%$, spathulenol $13.3 \%$ (B. variegata) the major constituents in Bauhinia volatile oils ${ }^{21}$.

\section{Conclusion}

We found phytol (62.17-90.38\%) as the major constituent in leaf oils of Bauhinia purpurea, B. scandens and B. malabarica from south India. B. acuminata also showed $65.91 \%$ of phytol in its leaf oil ${ }^{8}$. B. tomentosa showed only $10.12 \%$ phytol in its leaf oil. 


\section{ACKNOWLEDGEMENTS}

The authors thank Head, Department of Chemistry and Principal, Mar Ivanios College, Thiruvananthapuram for providing laboratory facilities. The authors also acknowledged Textile Committee, Kannur for GC-MS analyses.

\section{REFERENCES}

1. K.R. Kirtikar and B.D. Basu, Indian Medicinal Plants, International Book Distributors, Dehradun (1975).

2. The Wealth of India, Raw Materials, Council of Scientific and Industrial Research, Publication and Information Directorate, New Delhi (1952).

3. C. Meyre-Silva, R.A. Yunes, F.D. Monache, A.R.S. Santos, L.O. Schmeling, V.M. Gadotti, F.H. Liz and V. Cechinel-Filho, Z. Naturforsch C, 56, 939 (2001).

4. J.M. Watt and M.G. Breyer-Brandwijk, The Medicinal and Poisonous Plants of Southern and Eastern Africa, E. \& S. Livingstone, Edinburgh (1962).

5. H.D. Neuwinger, African Traditional Medicine: A Dictionary of Plant Use and Applications, Medpharm Scientific Publishers, Stuttgart, Germany (2000).

6. R.N. Yadava and S. Sodhi, Asian J. Chem., 13, 529 (2001).

7. G.M. Wassel, S.M.A. Wahab and N.M. Ammar, Sci. Pharm., 54, 357 (1986).
8. V. Vipinlal, J. Mathew and B. Sabulal, Asian J. Chem., 25, 2329 (2013).

9. R.P. Adams, Identification of Essential Oil Components by Gas Chromatography/Quadrupole Mass Spectroscopy. Allured, Carol Stream (2007).

10. D. McGinty, C.S. Letizia and A.M. Api, Food Chem. Toxicol., 48, S85 (2010).

11. T. Netscher, Vitam. Horm., 76, 155 (2007)

12. A. Daines, R. Payne, M. Humphries and A. Abell, Curr. Org. Chem., 7, 625 (2003).

13. J.H. Baxter, J. Lipid Res., 9, 636 (1968).

14. F.V. Vencl and T.C. Morton, Chemoecology, 8, 25 (1998).

15. F. Maggi, T. Bílek, D. Lucarini, F. Papa, G. Sagratini and S. Vittori, Food Chem., 113, 216 (2009).

16. F. Maggi, P. Mártonfi, F. Conti, G. Cristalli, F. Papa, G. Sagratini and S. Vittori, Chem. Biodivers., 8, 2057 (2011).

17. S. Budavari, The Merck Index: An Encyclopedia of Chemicals, Drugs and Biologicals, Merck \& Co Inc, New Jersey, edn. 12, p. 308 (1996).

18. M. Skold, A.T. Karlberg, M. Matura and A. Borje, Food Chem. Toxicol., 44, 538 (2006).

19. Y. Tambe, H. Tsujiuchi, G. Honda, Y. Ikeshiro and S. Tanaka, Planta Med., 62, 469 (1996).

20. C. Ghelardini, N. Galeotti, L. Di Cesare Mannelli, G. Mazzanti and A. Bartolini, IL Farmaco, 56, 387 (2001).

21. J.M. Duarte-Almeida, G. Negri and A. Salatino, Biochem. Syst. Ecol., 32, 747 (2004). 